19 Revue d'histoire du XIXe siècle

Société d'histoire de la révolution de 1848 et des

révolutions du XIXe siècle

18 | 1999

Varia

\title{
Élargissement de la citoyenneté, limitation de la naturalisation : la conscription, pierre de touche du débat
}

Annie Crépin

\section{OpenEdition}

\section{Journals}

Electronic version

URL: http://journals.openedition.org/rh19/145

DOI: $10.4000 /$ rh19.145

ISSN: $1777-5329$

Publisher

La Société de 1848

Printed version

Date of publication: 1 June 1999

ISSN: 1265-1354

\section{Electronic reference}

Annie Crépin, «Élargissement de la citoyenneté, limitation de la naturalisation : la conscription, pierre de touche du débat », Revue d'histoire du XIXe siècle [Online], 18| 1999, Online since 10 September 2008, connection on 02 May 2019. URL : http://journals.openedition.org/rh19/145; DOI : 10.4000/ rh19.145

This text was automatically generated on 2 May 2019.

Tous droits réservés 


\title{
Élargissement de la citoyenneté, limitation de la naturalisation : la conscription, pierre de touche du débat
}

\author{
Annie Crépin
}

\section{ABSTRACTS}

The extension of citizenship and the limits to naturalisation: conscription as the cornerstone of the debate People are seldom aware that the institution of military service in the 19th century was debated together with the making of French citizenship. One of the stakes common to both debates was the duty of the foreigner regarding military service (which was seen as a burden). Exemption was always a "privilege" which had to disappear for the sake of egalitarianism. But, of course, any extension of the military service led to defining rules and standards which showed antagonistic conceptions of French identity. How was it possible to assert the national character of the army without granting civic rights? Should a voluntary demand be required, or should naturalisation be automatic? How many generations were needed to obtain French citizenship? Should naturalisation be extended? All of these questions, which had been asked in 1831 and in 1848, were settled only in 1889 -by the law of June 1889 which reached the second generation, and by that of July 1889 which created the republican version of military service.

On ignore souvent qu'au siècle dernier, la mise en place du service militaire a été débattue en parallèle avec la construction de la citoyenneté française. L'un des enjeux communs à ces deux débats est le devoir de l'étranger à l'égard de la conscription, perçue comme un fardeau. 
L'exemption relève toujours du "privilège " qui au nom de l'égalitarisme doit être supprimé. Mais bien entendu toute extension du service militaire conduit à définir des règles et des normes qui font affleurer des conceptions antagonistes de l'identité française. Comment affirmer le caractère national de l'armée sans accorder de droits civiques? Doit-on privilégier une démarche volontaire sur l'automaticité ? À partir de combien de générations peut-on accorder la nationalité française? Doit-on étendre la naturalisation? Toutes ces questions posées en 1831 puis en 1848 ne seront réglées simultanément qu'en 1889, par la loi confèrant la nationalité à la seconde génération et celle créant la version républicaine du service militaire.

INDEX

Mots-clés: Conscription, Citoyenneté, Histoire militaire 